\title{
SOME SEA GRASSES FROM THE PHILIPPINES
}

$\operatorname{AUTHOR}(\mathrm{S})$ :

Cordero, Paciente A.

\section{CITATION:}

Cordero, Paciente A.. SOME SEA GRASSES FROM THE PHILIPPINES.

PUBLICATIONS OF THE SETO MARINE BIOLOGICAL LABORATORY 1981, 26(4-6): 319-325

ISSUE DATE:

1981-09-30

URL:

http://hdl.handle.net/2433/176036

RIGHT: 


\title{
SOME SEA GRASSES FROM THE PHILIPPINES ${ }^{1)}$
}

\author{
Paciente A. CORdero, Jr.
}

Division of Botany, Philippine National Museum, Manila

\section{Map 1 and Text-figures $1-3$}

\begin{abstract}
A morpho-taxonomic account of three species of sea grasses is reported. These are Enhalus acoroides (L. f.) Rich. ex Steud., Halophila ovalis (R. Br.) Hooker and Thalassia hemprichii (Ehrenb.) Ascherson, belonging to Family Hydrocharitaceae. The latter species, known in the Ilocos Region as "ballaiba", is eaten in that area in the form of salad.
\end{abstract}

\section{Introduction:}

To date the occurrence of sea grasses in Philippine waters is poorly reported. Availabla literature treat on Philippine marine phanerogams but superficially e.g. as part of an algal association. So far, only the work of Domantay (1), mentions eight species of sea grasses from Hundred Islands, Pangasinan. His list contains the following species:

\author{
Family: POTAMOGETONAGEAE \\ Cymodocea isoetifolia \\ Cymodocea sp. \\ Diplanthera enervis \\ Family HYDROCHARITACEAE \\ Enhalus acoroides \\ Halophila ovalis \\ Halophila sp. \\ Thalassia hemprichii \\ Posidonia sp.
}

Incidentally, his $C$. isoetifolia has been transferred to the genus Syringodium, $S$. isoetifolium and the species name of Diplanthera enervis should be corrected to $D$. uninervis. The latter taxon is now known as Halodule uninervis based on Tsuda et al.

1) Part of an on-going Museum Research Project on Philippine Marine Flora to be published in fascicle.

Publ. Seto Mar. Biol. Lab., XXVI (4/6), 319-325, 1981. (Article 16) 
(2) and Den Hartog (3 in part). Domantay observed these sea grasses inhabiting ".... muddy bottoms ...." together with few marine algae. However, his specimens are unavailable for further study to check specially the nomenclature of Cymodocea sp., Halophila sp., and Posidonia sp.

During the past years, the present investigator observed and collected considerable amount of sea grass specimens from various islands in the Philippines (Map 1), and now feels the necessity to report three most common and extensively distributed species, namely: Enhalus acoroides, Thalassia hemprichii and Halophila ovalis. Voucher specimens reported and deposited in the Philippine National Herbarium (PNH) and other herbaria as indicated by Index Herbariorum abbreviations.

- The author acknowledges the Philippine Government through the National Museum (PNH), the National Research Council of the Philippines (NRCP), and

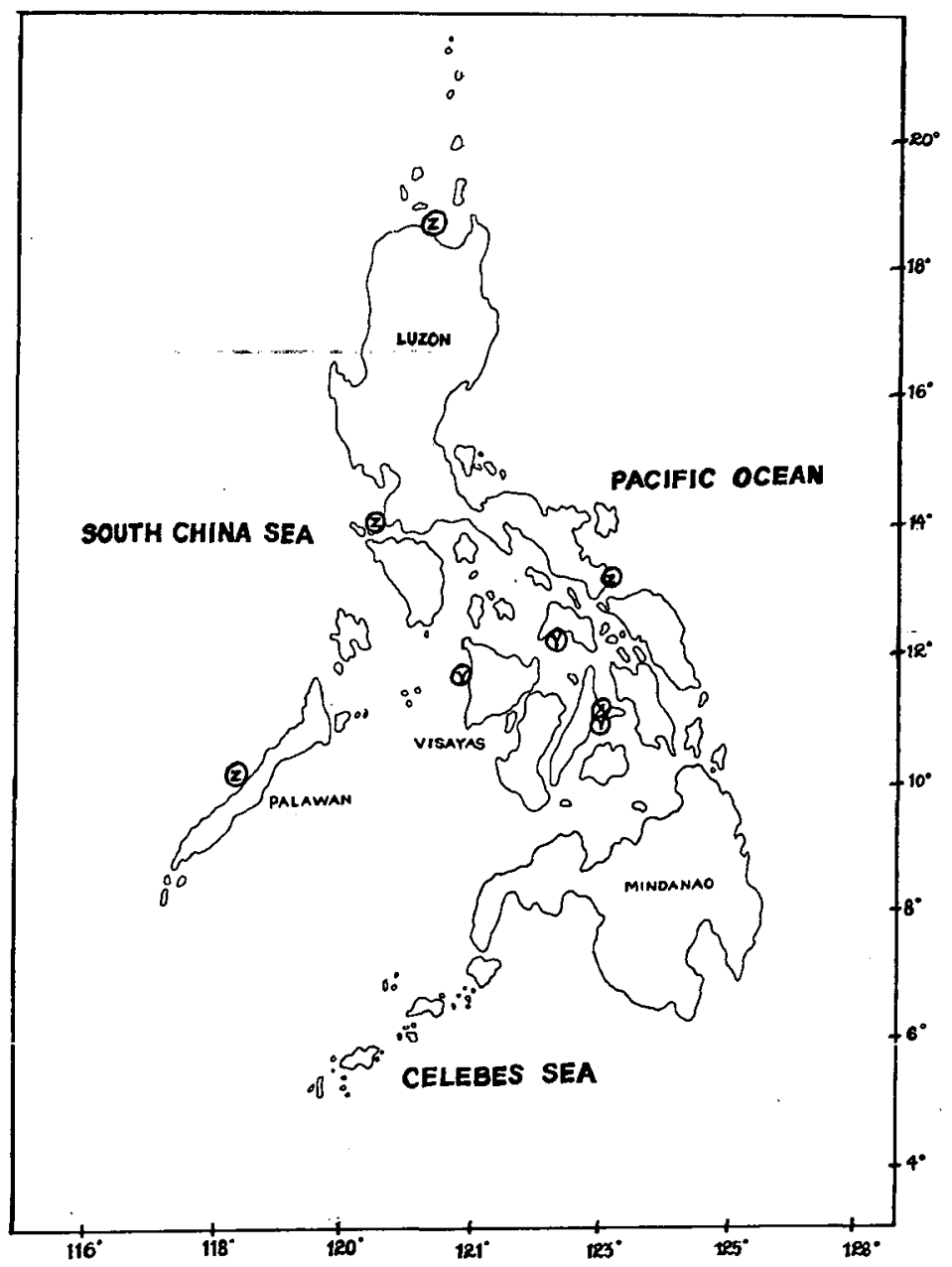

Map 1. Map of the Philippines showing the collecting areas of $E$. acoroides (X), $H$. ovalis (Y), and $T$. hemprichii $(Z)$. 
the Philippine Council for Agriculture and Resources Research (PCARR), for financial assistance and specially for the latter two agencies for the help extended by the attached research personnel (NRCP I.-98 and PCARR No. 693), who collected and illustrated the materials.

\section{Taxonomic Treatment:}

Specimens bearing numbers preceded by the author's initial (PC) will be accessioned later as part of the Philippine National Herbarium (PNH) collections. Designation of Phyco-geographical distributions follows that of Cordero (4).

\section{Family: HYDROCHARITAGEAE}

Key to the Genera:

1. Plants tall up to $80 \mathrm{~cm}$; erect; leaves linear-lanceolate; stolon/rbizome, well-developed.

1. Plants short, vertical part up to $40 \mathrm{~cm}$; creeping; leaves oval to ob-ovate; stolon slender. Halophila

2. Leaves barely to $20 \mathrm{~cm}$ long, lanceolate; rhizoid, cylindrical, few. Thalassia

2. Leaves tall at $-80 \mathrm{~cm}$ long, linear lanceolate; rhizoid cylindrical, numerous.

Enhalus

\section{Genus : Enhalus L. C. Richard}

Enhalus acoroides (L. F.) Rich. ex Steud.

Merr., Ennum, Philipp. Fl. Plants 1:27 (1925); Den Hartog, In Flora Malesiana, 5: 402 (1957) fig. 13; Tsuda et al., Distrib. Sea grasses in Micronesia 193(1957).

Stratiotes acoroides Linn.

Enhalus koenigii L. C. Rich.

Vallisneria sphaerocarpa Blanco

Plant colonial, tall at $60(-80) \mathrm{cm}$, composed of grass green vertical stem with ligulate, strap-shaped leaves and yellowish prostrate stolon held by means of massive cylindrical rhizoid. Leaves flat, linear lanceolate borne distichously, to $2.5 \mathrm{~cm}$ broad, up to $60 \mathrm{~cm}$ long. Tip of leaf bearing microscopic sharpish growths distributed equally. Stolon measures $1.0 \mathrm{~cm}$ in diameter, bearing many cylindrical roots covered with fibrous growths. Flower when present borne terminally by long, cylindrical and spiral-shaped stalk, white.

The tender leaves of $E$. acoroides or Laai (Tag.); Lamon (Tag., Bik); Marui-barui (Bik.); Palaipat-baibai and Bal-laiba (Ilk.); Bariau-bariau is eaten in the form of salad after thorough blanching.

Materials examined:

EASETRN VISAYAS - Cebu, Lapu-lapu City, Mactan Island, Punta Inganio, (PC-C5-79), Cordero and Perez, April 1979. 


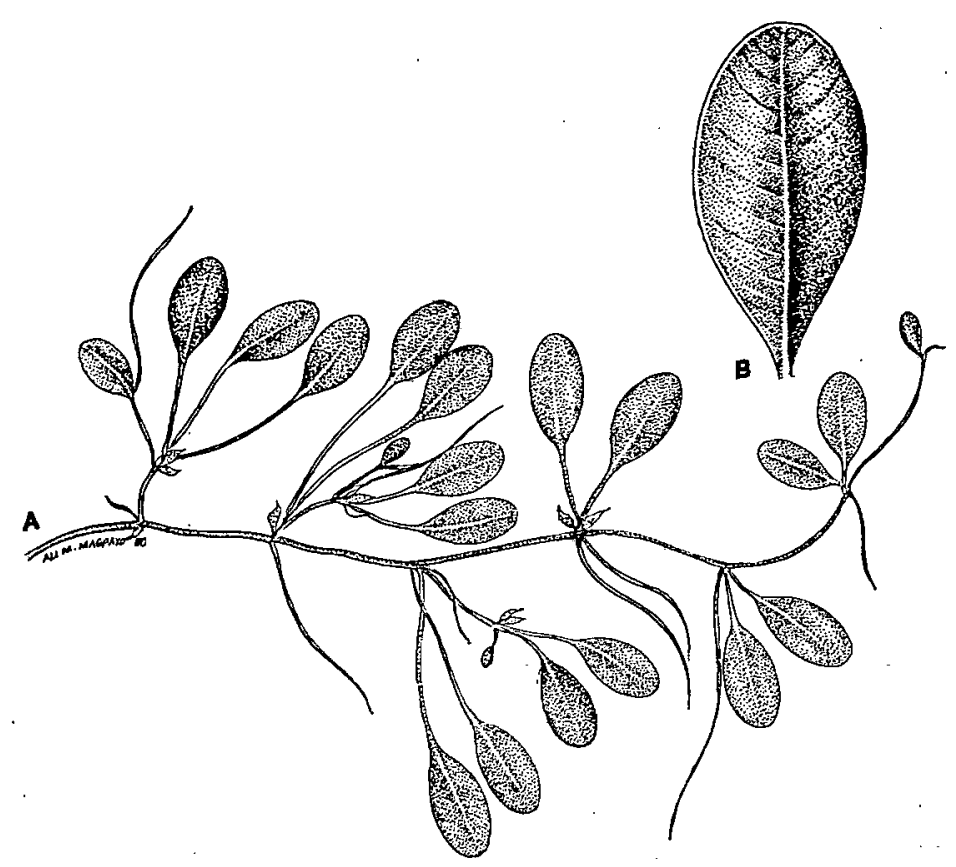

Fig. 1. A: Habit of Enhalus acoroides $(\times 1 / 3)$; B: Detailed upper portion of leaf: C: Detailed root system.

\section{Genus : Halophila Thouars}

Halophila ovalis (R. Br.) Hooker

Merr., Flora of Manila 70(1912); Ibid,. Ennum. Philipp. F1. Plants 1:26 (1925);

Dawson, Mar. Plants in Vicinity of Oceanogr. de Nha Trang, Vietnam 8:356 (1954) fig. 1 d-f.; Den Hartog, In Flora Malesiana 408(1957) fig. 16; Domantay, Ecol. Survey Mar. Veget. Hundred Islands and Vicinity, 9:275 (1963); Chihara, Common Seaweeds of Japan in Color 116(1970) pl. 50, fig. 5; Tsuda et al., Distrib. Sea gasses in Micronesia, 195(1977).

Halophila minor (Zoll.) Hartog.

Caulinia ovalis $\mathrm{R}$. Br.

Halophila ovata Gaudichaud

Plant colonial, creeping, composed of an upright stalk bearing leaves at irregular intervals and branching cylindrical stolons issuing roots at intervals. Leaves green, oval to ob-ovate usually paired, to $2 \mathrm{~cm}$ long, $1.0-1.2 \mathrm{~cm}$ broad; secondary pinnate veins 11-14; petiole to $3 \mathrm{~cm}$ long. Stolon yellowish barely $0.8 \mathrm{~cm}$ in diameter with rarely branched roots underneath where leaves arise.

Materials examined:

EASTERN VISAYAS-Gebu, Lapu-lapu City, Mactan Island, Punta Inganio; (PC-C1-79), Cordero and Perez, July 1979; Cebu, Mocaboc Island; (PC-C3-79). Cordero and Perez, July 1979; Cebu, Santa Rosa Island, (PG-C4-79), Cordero and Perez, October 1979.

WESTERN VISAYAS-Antique, Culasi, Batbatan (PC-Al-79), Cordero and 


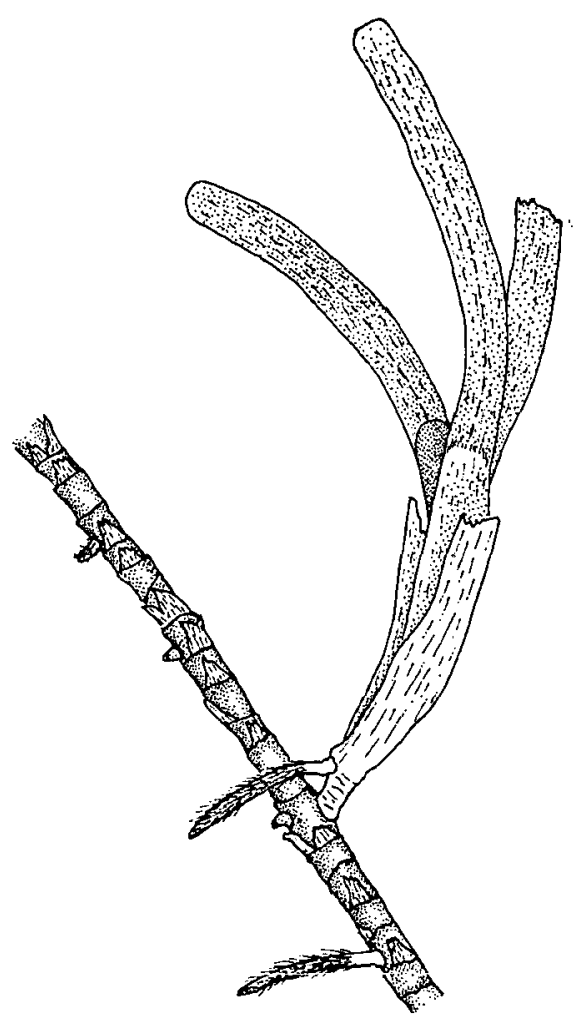

Fig. 2. A: Portion of habit of Halophila ovalis with pronounced prostrate stolon and root system $(\times 1) ;$ B: Detailed leaf $(\times 1.5)$.

Perez, April 1979. Masbate, Milagros, Nagarang, (PC-M1-79), Cordero and Perez, May and December 1979; Masbate, Malbug, Hilutungan, (PC-M2-79), Cordero and Perez, May and December 1979.

Type Locality:

Tropical Australia

Plants were found in sandy-muddy bottom with Caulerpa and other codiaceous marine algae.

The Philippine materials have narrower leaves compared to the Japanese materials described by Chihara (5) which measures $2.5-4 \mathrm{~cm}$ long and $1 \mathrm{~cm}$ broad. However, the Japanese materials appear to have short petiole to almost sessile compared to our materials which are definitely petiolate measuring as long as $3 \mathrm{~cm}$ long. Dawson's (6) Vietnamese materials show very close affinity in gross-morphology with the Philippine materials.

\section{Genvs : Thalassia Banks}

Thalassia hemprichii (Ehrenb.) Ascherson

Merr., Flora of Manila 71 (1912); Ibid., Ennum. Fl. Plants 1:27 (1925); 
Dawson, Mar. Plants in Vicinity of Inst. Oceanogr. de Nha Trang, Vietnam 8:377 (1954) fig. 2g; Den Hartog, In Flora Malesiana 408(1957) fig. 15; Tsuda et al., Distrib. of Sea grasses in Micronesia 1954 (1977).

Schizotheca hemprichii Ehrenb.

Zostera marina sensu Gaudichaud, non. L.

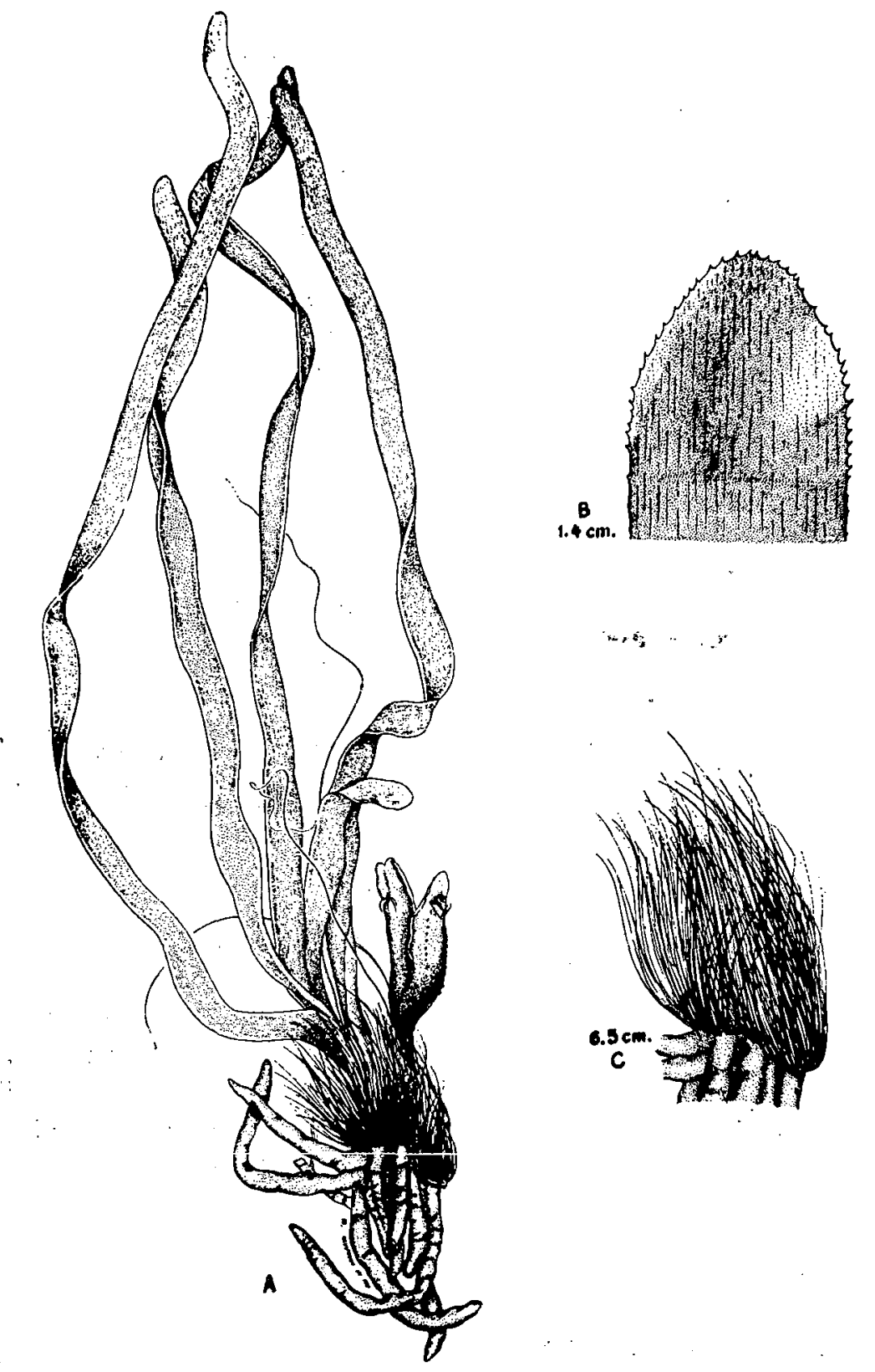

Fig. 3. A: Habit of Thalassia hemprichii $(\times 1)$. 
Plant colonial, 19(-20) cm, composed of grass green upright shoot bearing ligulate, strap-shaped leaves and yellowish creeping cylindrical rhizome anchored by means of cylindrical root system. Leaves flat, linear lanceolate borne distichously, to $1.0 \mathrm{~cm}$ broad, up to $20 \mathrm{~cm}$ long. Tip of leaf bearing microscopic sharpish teethlike growths paced equidistantly. Rhizome clearly showing nodes, to $.0 .5 \mathrm{~cm}$ in diameter, bearing few cylindrical roots covered with fibrous growths.

Materials examined.

NORTHEASTERN LUZON-Gagayan, Aparri, PNH 112262, Cordero-GutierrezReynoso, March 1973; Sorsogon, Gubat, PNH 42579, Pancho, March 1962.

NORTHWESTERN LUZON-Batangas, Calatagan, Pandak Is., PNH 113552, Gonzales et al., December 1971.

SOUTHWESTERN or Mindanao-Sulu-Palawan, Quezon, PNH 94846, Reynoso, December 1963.

Type Locality:

Red Sea

Growing mixed with caulerpaceous, codiaceous and few Sargassum species in muddy substratum.

Our plants compare easily with those described and illustrated by Domantay (1) from Pangasinan, Dawson (6) from Vietnam, and Chihara (5) from Japan (as Zostera marina), based on their gross morphological features.

Note:

Several epiphytes and epizoic organisms, collected from the thalli of $E$. acoroides and $T$. hemprichii, will be treated in a separate paper.

\section{Literature Gited}

J. Domantay (190I). Philipp. J. Sc. 90: 271.

R. Tsuda, F.R. Fosberg and M.H. Sachet (1977). Micronesica 13: 191.

C. Den Hartog (1960). Pac. Naturalist 1(15): 3-8, 2 figs.

P.A. Cordero, Jr. (1977). Publ. Seto Mar. Biol. Lab., Spec. Publ. Ser., Vol. 4, 258 pp, 268 text-figs., 28 pls., 1 map.

M. Chihara (1970). Common Seaweeds of Jap. 173 p.

E.Y. Dawson (1954). Pac. Sci. 8: 373, 63 figs. 